\title{
TO THE QUESTION OF LANGUAGE STUDIES INFLUENCE ON SOCIAL, CULTURAL AND ETHNIC IDENTITY OF THE NATION (THE CASE OF THE KIMBUNDU LANGUAGE)
}

\author{
(C) 2020 Elena Evina, Liliya Kuznetsova, Victoria Chimankpa Egejuru
}

EVINA Elena Igorevna, PhD (Biology), Associate Professor of the Department of Social Sciences of the Higher School of Economics, Russian Federation, 101000, Moscow, Myasnitskaya str., 20.

KUZNETSOVA Liliya Vasilyevna, National Research University "Higher School of Economics", Dr.Sc. (Philology), Professor of the Department of Social Sciences, Higher School of Economics, Russian Federation, 101000, Moscow, Myasnitskaya str., 20, email: lilavas@ya.ru

EGEJURU Victoria Chimankpa, PhD Student, National Research University "Higher School of Economics”, 101000, Moscow, Myasnitskaya str., 20, email: lilavas@ya.ru

Abstract. The research is devoted to socio-linguistic, ethnic and cultural issues of the language investigations into one of the national languages of the Republic of Angola. Special attention is paid to the history of Kimbundu, its prevalence, influence on the Angolan Portuguese, literature and the musical culture of the country. The paper also focuses on the importance of maintaining interest in the language researches in Angola, Brazil and Russia. Summarising and analysing the accumulated material, the authors point out the contribution of the language studying practice to the solution of various tasks, scientific, cultural, humanitarian.

Keywords: Kimbundu, Bantu languages, socio-linguistic aspects of language inquiries, ethnic and cultural identity of the nation

DOI: $10.31132 / 2412-5717-2020-50-1-82-87$

Kimbundu (northern Mbundu) refers to the Bantu group of Benue-Congolese family and is one of national languages of Angola, along with Umbundo, Kikongo, Nganguela, Chokve and Kvanyama. Kimbundu is widespread mainly in the North-central part of the country: provinces Luanda, Malanje, Bengo, Cuanza Norte, Cuanza Sul and partly in Uige. The language is subdivided into several dialects (Njinga, Mbaka, Mbamba and Ngola), depending on the region. According to M. Gasri's classification Kimbundu refers to zone N [1].

Kimbundu is the language of the ethnicity of Ambundu. The first mentions of it can be referred to the $16^{\text {th }}$ century when Ambundu had states of Ndongo and Matamba in the territory of contemporary Angola [2]. With arrival of the Portuguese to Angola the language obtained its written form on the basis of the Latin alphabet. During the colonial period the next key events connected with studying and research of Kimbundu can be distinguished. In 1642 the first catechism in the language of Kimbundu written by the priest Francisco Pacconio was published. In 1697 the first work on grammar of Kimbundu was written in Brazil and published in Lisbon by the priest Pedro Dias. Then, in 1888-89, the grammar of Kimbundu by Heli Chatelain, a Swiss missionary and abolitionist, was released. In 1893 the Angolan poet, journalist, linguist and educator Joaquim Dias Cordeiro da Mata published a textbook on grammar of Kimbundu. In a year he published a Kimbundu-Portuguese dictionary. In 1903 José Pereiro de Nascimento published a Portuguese-Kimbundu dictionary. In 1934 José Luís 
Quintão published a revised grammar of Kimbundu. The same year António Assis Junior published a Kimbundu-Portuguese dictionary.

It should be mentioned that in the $17^{\text {th }}-$ the first half of the $18^{\text {th }}$ centuries Kimbundu was the main language of daily communication in Luanda. However, the decree adopted in 1765 limited the use of the national languages in child care educational institutions, and after the decree of 1919 the national languages were forbidden at schools, and Portuguese became compulsory. So, the national languages were used unofficially for a considerable part of the colonial period in Angola; they were spoken, as a rule, only in families and other closed communities [3]. At the same time, as the data given above show, almost all this time Kimbundu remained a subject to close attention and scrupulous studying by Europeans, and then by Angolans themselves.

Since the declaration of independence of Angola in 1975 studying of the national languages has been in a varying degree supported by the state. However, under the influence of globalization in large cities among youth and the educated population there can be observed a refusal to study the national languages in favour of European languages (as a rule, English). At the same time it should be noted that about 75 per cent of the population of the country live in rural areas where conservative trends prevail and the use of the national languages is more common in daily communication.

How do these multidirectional factors affect prevalence of Kimbundu? In 1967 about 1.3 million people spoke Kimbundu, in 1990 - 3 million people. In 2014, according to the data of the Angolan National Institute of Statistics, Kimbundu is used as a first or second language by 2.1 million people [3].

Let us consider how Kimbundu is presented in the culture and mass media of Angola and what initiatives are used in the country for maintaining the interest in the language. In 1978 the Institute of National Languages was founded.

In the second half of the $20^{\text {th }}$ century there appeared certain linguistic researches devoted to the Angolan Portuguese [4]. The authors note considerable influence of Kimbundu onto Angolan Portuguese, in particular, numerous borrowings from Kimbundu to Portuguese [5]: kamba (friend), muxima (heart), kota (an elder person), cassule (the youngest child), malembe (slowly), matumbo (silly), sakidila (thanks), kambuta (a short person), tuji (excrement), musseque (slum), ndengue (child).

The national radio of Angola (Rádio Nacional de Angola) and the radio 'Our Angola' (Ngola Yetu) broadcast in all national languages, including Kimbundu. The central TV channel of Angola TPA1 daily allocates broadcasting time for delivering news in Kimbundu. In 2004-2010 at the initiative of the National Institute of Researches and Development of Education Kimbundu was introduced as a school subject in elementary grades in schools of the province of Cuanza Norte. In 2016 TPA reported that Kimbundu was being studied by pupils of elementary grades in Rangel, one of the districts of Luanda [6]. In 2011 a Kimbundu-Portuguese and Portuguese-Kimbundu dictionary by Júlio António (Juju Kamuxitu) containing 5000 entries was published.

The initiatives of certain people (as a rule, youth), interested in studying of Kimbundu and sharing the knowledge with others, should also be noted. For instance, Gelson Caculu records video lessons on Kimbundu and publishes them on his channel on Youtube.com [7].

In 2014-2015 in Angola a television series Jikulumessu was released. It is remarkable that for the series shot and broadcast in Portuguese the name was chosen in the language of Kimbundu (its name is translated as 'Open eyes'). Besides Angola, the series were shown in Brazil and also in Nigeria, Portugal and France.

Kimbundu is the language of traditional musical and dancing genres of Angola: semba and kizomba, kuduro and rebita. One of the cult performers of 60-70-ies of the $20^{\text {th }}$ century David Zé performed some of the compositions in Kimbundu. During this period the influence of Kimbundu on the musical culture was so prominent that many groups of non-Angola origin 
studied Kimbundu on purpose [8]. Elias Dia Kimuezu considered in Angola the "king" of music also sings in Kimbundu. His most known compositions in Kimbundu are 'Kalumba' ('Little girl') and 'Pangue iami' ('My brother'). Bonga, an Angolan singer and composer who released 42 albums and collections for 42 years of his career, also performs some of his works in Kimbundu. Modern performers of semba, kizomba and kuduro, such as Puto Português, Yury da Cunha, sing both in Portuguese and in Kimbundu.

On December 6, 2018 a cover version of the known hit by Luís Fonsi 'Despacito' - 'De Caxito' ('From Kashitu') was published on Youtube.com. The song was performed in Kimbundu by the popular Angolan singer Tinu Silva, a native of the city of Kashitu in the Province of Bengo.

Let us consider the importance of the language of Kimbundu in the context of formation of the Angolan literature which refers to the end of the $19^{\text {th }}$ century. The educational newspapers 'O farol do povo' ('The People's Beacon), 'A verdade' ('Truth') and 'O arauto africano' ('The African Herald') issued during this period were published both in Portuguese and in Kimbundu [9]. The political figure and poet of the second half of the $20^{\text {th }}$ century Mário Pinto de Andrade wrote in Kimbundu [10]. As it has been already mentioned, Kimbundu had significant influence on Angolan Portuguese in which the famous Angolan writers José Luandino Vieira, José Eduardo Agualuza and Artur Pestan (Pepetela) create their works. The poet António Marques should also be mentioned, whose works were published in Kimbundu, and then translated into Portuguese, English and Swedish, all books by the author being published in Sweden. One of the most famous poems by A. Marques is called 'Zwelenu o dimi dyetu' ('Let us Speak in our Language'). The poem 'Kusanya kuzola kwa muxima' ('Sowing Love Everywhere') by another contemporary Angolan poet, Mário Pereira, was published in the magazine 'Cultura. Jornal angolano de artes e letras' on November 23, 2014 [11].

How did the language of Kimbundu in Brazil develop? By some estimates, more than 4 million slaves whose considerable part belonged to the people of Ambundu [12] were taken from the African continent to Brazil during the period of $16-19^{\text {th }}$ centuries. In this regard, Kimbundu had a considerable impact on Portuguese and the culture of Brazil. A number of researchers believe that the Brazilian dance samba comes from the Angolan semba, pointing out similar dancing elements - umbigada - dancers' movements towards each other before contact of stomachs or with imitation of this contact. As far as the Brazilian Portuguese is concerned, such words as 'moleque' (boy), 'mucama', (servant), 'quitanda' (fair), 'bunda' (back) and many others are borrowed from Kimbundu and are often used in colloquial speech [13]. In 2002 the famous Brazilian singer Joana performed a song called 'Muxima' ('Heart') in Kimbundu. The Brazilian poet, composer and singer Tigana Santana also uses Kimbundu: one of his famous compositions in this language is 'Monami' ('My son').

Apart from its cultural influence, Kimbundu is rather a widespread subject to scientific research in Brazil, especially in São Paulo. Thus, in the University of São Paulo students are offered the course of Kimbundu. At the same university in 2010 Francisco da Silva defended his dissertation on segmental and suprasegmental phonology of the language of Kimbundu [14]. The author considers the phonetic system of Kimbundu in detail syllables, the accent and the tone system, which is in general characteristic of the Bantu languages. Moisés Álves Augusto from the Catholic University of São Paulo conducted a big research on grammar of Kimbundu, interaction of Kimbundu and Portuguese and the history of studying of Kimbundu and in 2016 defended the dissertation on this subject [15]. In 2018 the mobile application for studying of the Kimbundu language in Brazilian schools was reported to be created [16].

As for Russia, first of all, it should be mentioned that researchers of St. Petersburg State University have been engaged in profound studying of the national languages of Angola for long. At the Professor A. Zhukov's initiative elective courses on Kimbundu and 
Kikongo were organized [17]. In September, 2005 the authorities of St. Petersburg University met a high delegation from Angola. The participants of the meeting organized a joint Russian-Angolan conference on culture and the national languages of Angola [18]. St. Petersburg University newspaper reported: “... Professor Amélia Arlete Mingas, the head of the linguistic department of the Higher Institute of Pedagogical Sciences, illustrated her speech 'National Languages and Cultural Identity' with numerous examples from oral tradition of the people of Angola, such as 'Portuguese teaches, Kimbundu explains', 'A hand washes the other. Two hands wash the face', etc. As Amélia Mingas stated, according to these and other sayings it is possible to make an idea of the system of values of the people of the Republic of Angola".

Nowadays in Russia no researches devoted to Kimbundu are conducted, and the interest in national languages of Angola in the academic environment in general has declined. A Russian-Kimbundu and Kimbundu-Russian dictionary can be found on Glosbe.com, one of the largest multilingual electronic dictionaries with a translation memory (i.e. with examples of use of a particular word in various texts), but this resource needs significant expansion and addition [19]. Printed dictionaries or textbooks in Kimbundu have not been published in Russia.

At the same time, the musical and dancing genres of kizomba and semba are very popular in certain circles in Russia. In spite of the fact that the formation of these genres (mainly kizomba) is greatly contributed by the culture of Cape Verde, Guinea-Bissau and Portugal, Angolan performers still play an important role. Their songs, including ones performed in Kimbundu, can be regularly heard at dancing parties and kizomba festivals: for instance, the song 'Monami' by the famous Angolan singer Puto Português in fact was a hit of 2013-2014. At the same time it should be noted that not all admirers of the Angolan music and dances in Russia have an idea even of the existence of the language of Kimbundu. As a rule, Kimbundu is mentioned in dance schools websites, in descriptions of dances (semba, kizomba and kuduro) and the musical directions: '.. the language of songs is Portuguese, often with impurity of the Angolan dialects, for example, Kimbundu (the main language of the people of Ambundu (Mbundu) and one of the most widespread in Angola)' [20].

Summing up the aforesaid, it is important to emphasize that the size of the population speaking Kimbundu has reduced in the last decades, however, Kimbundu remains one of languages of daily communication and means of translation of the Angolan culture. Interest in Kimbundu is observed not only in Angola, but also abroad, and maintenance of this interest will help to solve a number of crucial tasks.

Scientific tasks. Composing dictionaries, studying interaction of Kimbundu with other languages, studying dialects of Kimbundu are a good contribution to African Studies and comparative and historical linguistics.

Cultural tasks. Studying of Kimbundu can contribute to the maintainance of the Angolan culture and also will give foreigners the chance to get acquainted with the Angolan culture.

Humanitarian tasks. The Kimbundu language proficiency will allow experts (teachers, doctors, engineers, etc.) and volunteers to render their professional assistance in the regions (generally in rural areas) where Kimbundu is the main language of daily communication.

\section{References}

1. Hammarström H., Forkel R., Haspelmath M., eds. (2017). Kimbundu. Glottolog 3.0. Jena, Germany: Max Planck Institute for the Science of Human History.

2. Miller J. Kings and Kinsmen: Early Mbundu States in Angola. Oxford: Clarendon, 1976.

3. Vansina, Jan (2001). Portuguese vs Kimbundu: Language Use in the Colony of Angola (1575 c. 1845). Bull. Séanc. Acad. R. Sci. Outre-Mer Mede. Zitt. K. Acad. (in English). 47. 269 p. 
4. https://24.sapo.pt /piece of news/international / article / mais-de-sete-milhoes-de-angolanosfalam-linguas-nacionais_20523775.html (accessed 28.03.2016)

5. Yarushkin A.A. Portugalskiy yazyk v Angole. Dissertaciya na soiskanie uchenoy stepeni kandidata filologicheskih nauk, Leningradskiy gosudarstvennyy universitet imeni A.A. Zhdanova (Portugese in Angola. PhD Dissertation, Leningrad State University named after A.A. Zhdanov), Leningrad, 1984.

6. http://casadeluanda.blogspot.com/2008/03/dicionário-angolano-de-a-d.html (accessed 31.03.2008)

7. http://tpa.sapo.ao/piece of news /culture / projecto-Kimbundu-nas-escolas-do-rangel-abrangemais-de-2-mil-alunos (accessed 16.09.2016)

8. https://www.youtube.com/channel/UCL8NFkm9-06-0CF1nrnKt3A

9. Pereira L. Os regressados na cidade de Luanda: um estudo sobre identidade étnica e nacional em Angola. Dissertação de mestrado em Antropologia Social. Faculdade de Filosofia, Letras e Ciências Humanas da Universidade de São Paulo. 1999.

10. Ryauzova E.A. Angolskaya literatura na rubezhe XIX i XX vekov, Istoriya vsemirnoy literatury: $v 8$ tomah (Angolan Literature in 19-20 centuries, History of World Literature: in 8 volumes USSR Academy of Science), Institute of World Literature named after A.M. Gorki, Moscow, Nauka, 1983-1994, vol. 8, 1994, p. 702-704.

11. http://www.ueangola.com / index.php / bio-quem / item / 820-mário-coelho-pinto-deandrade.html (accessed 23.11.2014)

12. http://jornalcultura.sapo.ao / letter / poema-kimbundo-de-mario-pereira (accessed 23.11.2014)

13. Brito E.J., Malandrino B.C. (Dezembro de 2007). História e Escravidão: Cultura e Religiosidade Negras no Brasil - Um Levantamento Bibliografico. Revista de Estudos da Religião. Consultado em 15 de dezembro de 2017.

14. Ferreira A. B. H. Novo dicionário da língua portuguesa. Segunda edição. Rio de Janeiro. Nova Fronteira. 1986.

15. Da Silva F. Fonologia segmental e supra-segmental do quimbundo (Tese apresentada ao programa de Pós Graduação em Semiotica e Lingüística Geral do Departamento de Lingüística da Faculdade de Filosofia, Letras e Ciências Humanas da Universidade de São Paulo para a obtenção do título de Doutor em Lingüística). São Paulo, 2010.

16. Augusto M.A. Morfologia contrastiva entre português e kimbundu: obstáculos e suas causas na escrita e ensino da língua portuguesa entre os kimbundu em Angola (Tese apresentada à Banca Examinadora da Pontifícia Universidade Católica de São Paulo, como exigência parcial para obtenção do título de Doutor em Língua Portuguesa sob a orientação do professor Doutor João Hilton Sayeg de Siquera). São Paulo, 2016.

17. https://www.youtube.com/watch?v=_SvGuPjP3k0 (accessed 03.03.2018)

18. http://angolarussia.ru/publications/press-releases-articles-reports/460-russia-in--petersburgstudy-national-languages-of-angola.html?lang=en (accessed 16.08.2004)

19. http://www.spbumag.nw.ru/2005/20/5.shtml (accessed 29.09.2005)

20. https://glosbe.com/kmb/ru/ (accessed 23.11.2014) 


\title{
К ВОПРОСУ ВЛИЯНИЯ ИССЛЕДОВАНИЙ ЯЗЫКА НА СОЦИАЛЬНО-КУЛЬТУРНУЮ И ЭТНИЧЕСКУЮ ИДЕНТИЧНОСТЬ НАЦИИ (НА ПРИМЕРЕ ЯЗЫКА КИМБУНДУ)
}

\author{
(ㄱ) 2020 Е.И. Евина, Л.В. Кузнецова, В.Ч. Егеджуру
}

ЕВИНА Елена Игоревна, кандидат биологических наук, доцент Департамента социальных наук НИУ ВШЭ, Российская Федерация, 101000, Москва, ул. Мясницкая, д. 20. email: 1_evina@ list.ru

КУЗНЕЦОВА Лилия Васильевна, доктор филологических наук, профессор Департамента социальных наук НИУ ВШЭ, Российская Федерация, 101000, Москва, ул. Мясницкая, д. 20. email: lilavas@ya.ru

ЕГЕДЖУРУ Виктория Чиманкпа, соискатель Департамента социальных наук НИУ ВШЭ, Российская Федерация, 101000, Москва, ул. Мясницкая, д. 20, email: lilavas@ ya.ru

Аннотация. Исследование посвящено сочиально-лингвистическим и этнокультурным вопросам исследований одного из начиональных языков Республики Ангола. Особое внимание уделяется истории кимбунду, его распространённости, влияния на ангольский вариант португальского языка, литературу и музыкальную культуру страны. Также в работе подчёркивается важность поддержания интереса к исследованиям языка в Анголе, Бразилии и России. Обобщзая и анализируя собранный материал, авторы выделяют вклад практики изучения языка в решение различных задач, как научных, так и культурных, гуманитарных.

Ключевые слова: кимбунду, языки банту, соииально-лингвистические аспекты исследований языка, начиональная этнокультурная идентичность

DOI: $10.31132 / 2412-5717-2020-50-1-82-87$ 